\title{
Acetonitrile-based electrolytes for lithium-ion battery application
}

\author{
Peter Hilbig ${ }^{1}$, Lukas Ibing ${ }^{1}$, Benjamin Streipert ${ }^{1}$, Ralf Wagner ${ }^{1}$, Martin Winter ${ }^{1,2}$ \\ and Isidora Cekic-Laskovic ${ }^{2}$ \\ ${ }^{1}$ MEET Battery Research Center/Institute of Physical Chemistry, University of Münster, \\ Corrensstrasse 46, 48149 Münster, Germany; ${ }^{2}$ Helmholtz-Institute Münster, IEK-12, \\ Forschungszentrum Jülich GmbH, Corrensstrasse 46, 48149 Münster, Germany.
}

\begin{abstract}
Compared to the commercially used state-of-the art non-aqueous organic carbonate solvent-based electrolytes, acetonitrile (AN)-based electrolytes have the advantage of enabling higher conductivity and lower viscosity values. The beneficial influence of adding fluoroethylene carbonate (FEC), thus enabling AN compatibility with graphite anodes, in different ratios to AN-based electrolytes represents the main focus of this manuscript. Long-term cycling measurements at $0{ }^{\circ} \mathrm{C}$ and $20^{\circ} \mathrm{C}$ as well as conductivity and electrochemical stability measurements were performed to identify the optimal AN:FEC ratio. The electrochemical performance as well as the decomposition products were further investigated in graphite/lithium iron phosphate (LFP) cells to validate the applicability in lithium-ion cells.
\end{abstract}

KEYWORDS: lithium-ion batteries, acetonitrile, low temperature.

\section{INTRODUCTION}

Due to their higher energy density as well as their high energy efficiency, lithium-ion batteries (LIBs) represent the most dominant battery technology nowadays [1-4]. Furthermore, these systems deliver stable and long cycle life as well as low self-discharge. LIBs find application in portable electronic devices such as mobile phones and laptops as well as in the automotive industry, grid storage, medicine and military [5, 6]. This broad field of application calls for new electrolyte components and formulations to fulfil the wide spectrum of challenging requirements [7]. The demand of an electrolyte having both very high ionic conductivity and at the same time enabling low temperature LIB operation cannot be fulfilled by the common organic carbonate-based electrolytes $[8,9]$. A solvent class, which enables extraordinarily high ionic conductivities of the resultant electrolyte, refers to nitriles [10]. Among them, the most reported nitrile in literature is acetonitrile (AN), which has a low viscosity and a decent dielectric permittivity $[11,12]$. These two properties of AN lead to a superior high ionic conductivity of more than $30 \mathrm{mS} / \mathrm{cm}$ for AN-based electrolytes $[13,14]$. However, the disadvantage of $A N$ is related to its inability to form an effective solid electrolyte interphase (SEI) on both lithium metal and graphite electrodes [15-18]. Without an effective SEI, which ideally is permeable only for lithium ions, exfoliation of graphite as well as continuous electrolyte decomposition will inevitably take place $[19,20]$. To overcome this, a wide variety of electrolyte additives, able to tailor the SEI formation and dynamics, are under exhaustive research [21-25]. These additives decompose on the graphite surface and build an effective SEI, thus preventing the bulk electrolyte compounds (e.g. nitriles) from further decomposition $[21,26]$. Among well-known electrolyte additives, vinylene carbonate (VC) [27, 28], ethylene sulfite (ES) $[29,30]$, lithium bis(oxalato)borate (LiBOB) 
as well as fluoroethylene carbonate (FEC) have been thoroughly investigated in literature [23, 24, 31]. Among them, FEC is known to form an effective SEI on graphite and silicon electrodes and a cathode electrolyte interphase (CEI) [3234], on cathode materials [32, 35-38]. FEC has the advantages of having a higher decomposition potential $\left(1.5 \mathrm{~V}\right.$ vs. $\left.\mathrm{Li} / \mathrm{Li}^{+}\right)$compared to $\mathrm{VC}$ $\left(1.35 \mathrm{~V}\right.$ vs. $\left.\mathrm{Li} / \mathrm{Li}^{+}\right)$and the ability to form the effective SEI component lithium fluoride (LiF) during decomposition [39]. A possible decomposition mechanism of FEC was introduced by Etacheri et al., in which $\mathrm{LiF}$ is formed due to the abstraction of the fluoride group [40]. In literature, FEC is used as an additive for organic carbonate (especially propylene carbonate (PC))based electrolytes but it is also considered for other solvent classes [41, 42].

In this paper, the influence of different amounts of FEC in $1 \mathrm{M} \mathrm{LiPF}_{6}$ in AN-based electrolytes was investigated in terms of cycling performance of graphite/Li cells at different temperatures. In addition, the different AN:FEC blend-based electrolytes were used in graphite/ $\mathrm{Li}$ iron phosphate (LFP) cells. The cycled graphite electrodes were thereafter analyzed by means of X-ray photoelectron spectroscopy (XPS) sputter depth-profiling measurements.

\section{MATERIALS AND METHODS}

\subsection{Electrolyte preparation}

All electrolytes were prepared in a glovebox with a water and oxygen content below $0.1 \mathrm{ppm}$. AN (ACROS ORGANICS, extra dry 99.9\%), lithium hexafluorophosphate $\left(\mathrm{LiPF}_{6}\right)$ (BASF, battery grade) as well as FEC (Solvay, 99.9\%) were used as received. For all electrolytes, a $1 \mathrm{M}$ solution of $\mathrm{LiPF}_{6}$ in different $\mathrm{AN}: \mathrm{FEC}$ (vol.\%) ratios was formulated. $1 \mathrm{M} \mathrm{LiPF} 6$ in ethylene carbonate (EC):diethyl carbonate (DEC) (3:7 wt.\%) (BASF, battery grade) was used as the reference electrolyte.

\subsection{Electrode preparation}

\subsubsection{Preparation of T44 graphite electrodes}

T44 graphite was used due to its relatively high Brunauer-Emmett-Teller (BET) surface area, thus leading to increased electrolyte reduction and thus clear visibility of this reduction in electrochemical data [43]. The composition of graphite electrodes was 87 wt.\% T44 graphite (IMEREYS), 8 wt.\% polyvinylidene difluoride (PVdF) (Arkema) and 5 wt.\% conductive additive Super C65 (IMEREYS). The preparation procedure has been described in detail elsewhere [23].

\subsubsection{Preparation of lithium iron phosphate electrodes (LFP)}

To prepare LFP electrodes, a solution of PVdF (Arkema) in 1-methyl-2-pyrrolidinone (NMP) (ACROS ORGANICS, 99.5\% extra dry) (7 wt.\%) was formulated. In the next step, the conductive additive SuperC65 (IMERYS) (8 wt.\%) and LFP (Clariant) (85 wt.\%) were added to the binder solution. The suspension was thereafter dispersed and coated on the aluminum current collector (cleaned with ethanol prior to use). After the first drying procedure (overnight at $80^{\circ} \mathrm{C}$ in a drying oven), electrodes with a diameter of $12 \mathrm{~mm}$ were punched out and dried for $48 \mathrm{~h}$ at $120^{\circ} \mathrm{C}$ under reduced pressure.

\subsubsection{Preparation of lithium manganese oxide electrodes (LMO)}

The composition of the LMO $\left(\mathrm{LiMn}_{2} \mathrm{O}_{4}\right)$-based electrodes was $80 \mathrm{wt} \%$ LMO (Toda), $10 \mathrm{wt} \%$ PVdF (Arkema), and $10 \mathrm{wt} \%$ carbon black C65 (IMERYS). The electrode suspension was formulated in a similar way as in the case of LFP electrodes.

\subsection{Electrochemical measurements}

\subsubsection{Cell set-up}

The three-electrode (lithium metal) cell electrochemical measurements were performed in a Swagelok ${ }^{\circledR}$ T-cell setup. Lithium foil (Albemarle) was used for both the counter electrode (CE) and the reference electrode (RE). The two-electrode lithium-ion cell investigations were carried out in coin cell CR2032 (Hohsen Corp.) setup. In both cell configurations, FS 2226 (Freudenberg) was used as separator.

\subsubsection{Linear sweep voltammetry measurements}

The electrochemical stability window of the ANbased electrolytes was determined by means of linear sweep voltammetry (LSV). All measurements were carried out at room temperature $\left(20^{\circ} \mathrm{C}\right)$, using a Bio-Logic VMP3 potentiostat. A LMO 
composite electrode was used as the working electrode (WE), whereas lithium foil was used as the $\mathrm{CE}$ and $\mathrm{RE}$. The measurements were performed in the potential range between the open circuit potential (OCP) and $5.0 \mathrm{~V}$ vs. $\mathrm{Li} / \mathrm{Li}^{+}$, with a scan rate of $100 \mu \mathrm{V} \cdot \mathrm{s}^{-1}$.

\subsubsection{Cyclic voltammetry measurements}

All cyclic voltammetry (CV) measurements were carried out at room temperature, using a BioLogic VMP3 potentiostat, with graphite as the $\mathrm{WE}$ in the potential range between 0.02 and $2.00 \mathrm{~V}$ vs. $\mathrm{Li} / \mathrm{Li}^{+}$. The cells were cycled with a scan rate of $20 \mu \mathrm{V} \cdot \mathrm{s}^{-1}$. Lithium foil was used as the $\mathrm{CE}$ and $\mathrm{RE}$.

\subsubsection{Constant current-constant potential measurements}

Constant current-constant potential (CCCP) measurements were carried out at 0 and $20{ }^{\circ} \mathrm{C}$, respectively, using a battery cycler (MACCOR Series 4000). The graphite/Li cells were cycled in the potential range between 0.02 and $1.50 \mathrm{~V}$ vs. $\mathrm{Li} / \mathrm{Li}^{+}$, starting with three formation cycles at charge/discharge specific current of $37.2 \mathrm{~mA} / \mathrm{g}$ (corresponding to $\mathrm{C} / 10$, when considering a practical specific capacity of $372 \mathrm{mAh} / \mathrm{g}$ ). After the formation sequence, cells were further cycled with a charge/discharge specific current of $372 \mathrm{~mA} / \mathrm{g}$ (1C). Each intercalation step was followed by a constant potential (CP) step with $1 \mathrm{~h}$ duration at the potential of $0.025 \mathrm{~V} \mathrm{vs}$. $\mathrm{Li} / \mathrm{Li}^{+}$. For the LFP/Li cells, a potential range from 3.0 to $3.9 \mathrm{~V}$ vs. $\mathrm{Li} / \mathrm{Li}^{+}$was used, starting with three formation cycles with a charge/discharge specific current of $17 \mathrm{~mA} / \mathrm{g}(0.1 \mathrm{C})$. Afterwards, the cells were cycled at a $\mathrm{C}$-rate of $0.5 \mathrm{C}$ corresponding to a specific current of $85 \mathrm{~mA} / \mathrm{g}$.

\subsubsection{Constant current-constant voltage measurements}

The cathode-limited LFP/T44 graphite cells (15\% over sized anode in terms of capacity) were cycled with five formation cycles at $0.1 \mathrm{C}$ in the voltage range of 3.0-3.9 V. After the formation procedure, the $\mathrm{C}$-rate was set to $1 \mathrm{C}$ for the subsequent charge/discharge cycles.

\subsection{Conductivity measurements}

Alternating current $(\mathrm{AC})$ impedance measurements were carried out to determine the conductivity of the investigated AN-based electrolyte formulations. All measurements were performed on a Solartron 1260A impedance gain phase analyzer, connected to a Solartron 1287A potentiostat using a customized cell having two stainless steel diskelectrodes. A frequency range from $1 \mathrm{kHz}$ to $1 \mathrm{MHz}$ with an $\mathrm{AC}$ amplitude of $20 \mathrm{mV}$ was applied to cells for each temperature $\left(-40{ }^{\circ} \mathrm{C}\right.$ to $60{ }^{\circ} \mathrm{C}$ ) using a climate chamber (Binder) for temperature control.

\subsection{X-ray photoelectron spectroscopy analysis}

For the X-ray photoelectron spectroscopy (XPS) investigations, an AXIS Ultra DLD (Kratos) was used. An area of about $300 \mu \mathrm{m}$ x $700 \mu \mathrm{m}$ was irradiated, while using a filament voltage of $12 \mathrm{kV}$, an emission current of $10 \mathrm{~mA}$ and a pass energy of $20 \mathrm{eV}$. The spectra were calibrated against the carbon signal positioned at $284.6 \mathrm{eV}$. The electrodes were attached to the sample holder with a carbon double-side tape and transferred from a glovebox in sealed containers into the chamber of the XPS device. To ensure the removal of the remaining electrolyte, the samples were rested for $12 \mathrm{~h}$ in ultra-high vacuum. For the XPS sputter depth profiling measurements, a sputter crater diameter of $1.1 \mathrm{~mm}$, an emission current of $8 \mathrm{~mA}$ and a filament voltage of $0.5 \mathrm{kV}$ as well as a pass energy of $40 \mathrm{eV}$ and a $110 \mu \mathrm{m}$ aperture were applied.

\section{RESULTS AND DISCUSSION}

In order to overcome the aforementioned challenges related to incompatibility with graphite anodes, AN-based electrolytes were studied in combination with FEC as the co-solvent. The addition of FEC is expected to inhibit the decomposition of AN on both, graphite electrode and lithium foil, due to the formation of an effective SEI. To verify this, cyclic voltammetry measurements of T44 graphite/Li cells containing $1 \mathrm{M} \mathrm{LiPF} 6$ in 1:1 AN:FEC as electrolyte were performed, as depicted in Figure 1.

The decomposition of FEC starts at a potential of $\approx 1.6 \mathrm{~V}$ vs. $\mathrm{Li} / \mathrm{Li}^{+}$whereas the peak maximum is reached at the potential value of $1.5 \mathrm{~V}$ vs. $\mathrm{Li} / \mathrm{Li}^{+}$. Due to SEI formation, the decomposition of $\mathrm{AN}$ is inhibited, thus leading to reversible intercalation and deintercalation of lithium ions into the 


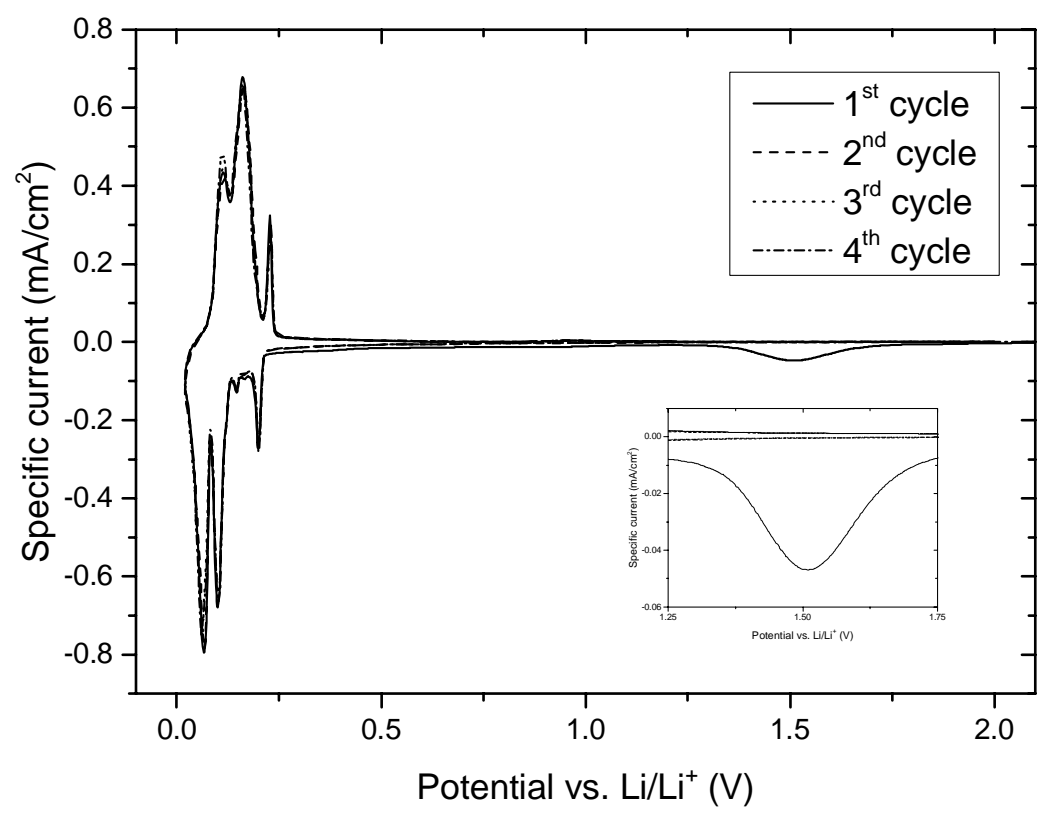

Figure 1. Cyclic voltammograms of a graphite/Li cell containing $1 \mathrm{M} \mathrm{LiPF}_{6}$ in $1: 1 \mathrm{AN}: \mathrm{FEC}$ electrolyte, in the potential range between $2.0 \mathrm{~V}$ vs. $\mathrm{Li} / \mathrm{Li}^{+}$and $0.02 \mathrm{~V}$ vs. $\mathrm{Li} / \mathrm{Li}^{+}$, at scan rate of $20 \mu \mathrm{V} / \mathrm{s}$; inset shows the magnification of the reductive decomposition peak of FEC at $1.5 \mathrm{~V}$ vs. $\mathrm{Li} / \mathrm{Li}^{+}$.

graphite host structure, as indicated by the presence of the intercalation/deintercalation peaks in Figure 1.

Long-term cycling performance was analyzed by means of CCCP cycling measurements of T44 graphite/Li cells. By varying the AN:FEC ratio, the optimal ratio in terms of cycling stability and cost, was determined, as FEC as co-solvent may increase the price of the electrolyte formulation. Figure 2 illustrates the galvanostatic cycling performance of the T44 graphite/Li cell containing $1 \mathrm{M} \mathrm{LiPF}_{6}$ in different ratios of AN:FEC electrolyte.

As no passivation of the graphite electrode was observed when using $1 \mathrm{M} \mathrm{LiPF}_{6}$ in AN:FEC (9:1) as the electrolyte, data is not shown here. Due to the low amount of FEC in the electrolyte, massive decomposition of $\mathrm{AN}$ takes place, thus leading to the exfoliation of the graphite electrode, and terminating the cell lifetime after only one charge/ discharge cycle $[44,45]$. Increasing the amount of FEC in the electrolyte advances the cycling performance of the graphite/Li cells. For this reason, a ratio of AN:FEC (8:2) was selected, as depicted in Figure 2a. Even though the cell can be cycled for 100 charge/discharge cycles, an increased capacity fading occurs from the first cycle onwards.
In the initial cycles, where SEI formation should take place, a specific discharge capacity of $\approx 350 \mathrm{mAh} / \mathrm{g}$ for the graphite electrode is reached. In the $100^{\text {th }}$ cycle, the capacity retention based on the $5^{\text {th }}$ cycle amounts to $83 \%$ indicating that the amount of FEC in the electrolyte is still not sufficient to fully prevent AN decomposition during long-term cycling at $1 \mathrm{C}$ in graphite/Li cells. For the cell cycled with $1 \mathrm{M} \mathrm{LiPF}$ in AN:FEC (7:3) (Figure $2 b$ ), the specific discharge capacity of graphite amounts to $\approx 360 \mathrm{mAh} / \mathrm{g}$ in the initial cycles. The capacity retention based on the $5^{\text {th }}$ cycle amounts to $99.7 \%$ in the $100^{\text {th }}$ cycle. Similar to the cycling stability, Coulombic efficiency values are constant during 100 charge/discharge cycles and reach the value of $\approx 99.6 \%$ in each cycle. In case of the $1 \mathrm{M} \mathrm{LiPF}_{6}$ in AN:FEC (6:4) electrolyte (Figure 2c), the specific capacity of graphite amounts to $\approx 360 \mathrm{mAh} / \mathrm{g}$, which is similar compared to the one reached with $1 \mathrm{M} \mathrm{LiPF}_{6}$ in AN:FEC (7:3) as electrolyte. After initial cycles, the capacity retention based on the $5^{\text {th }}$ cycle amounts to $99.8 \%$ in the $100^{\text {th }}$ cycle. Over 100 charge/discharge cycles, only negligible capacity fading occurs, which is also observed for the Coulombic efficiency values, which are, apart from 

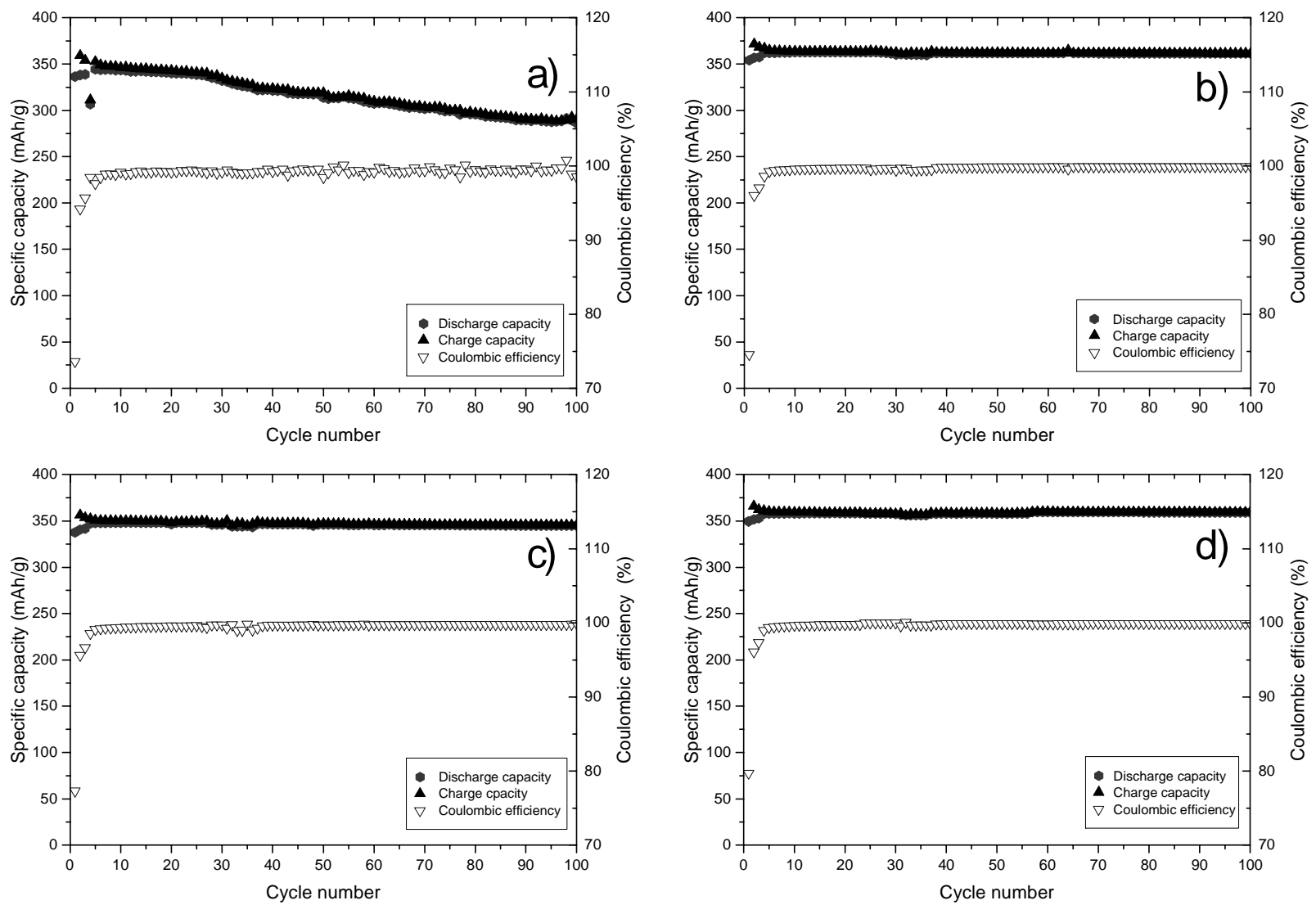

Figure 2. Cycling profiles of $\mathrm{T} 44$ graphite/Li cells containing a) $1 \mathrm{M} \mathrm{LiPF}_{6}$ in $\mathrm{AN}: \mathrm{FEC}(8: 2)$, b) $1 \mathrm{M} \mathrm{LiPF} 6$ in AN:FEC (7:3), c) $1 \mathrm{M} \mathrm{LiPF}_{6}$ in $\mathrm{AN}: F E C(6: 4)$ and d) $1 \mathrm{M} \mathrm{LiPF}_{6}$ in $\mathrm{AN}: \mathrm{FEC}(1: 1)$ as electrolyte formulations.

the initial cycles, always around $99.8 \%$. The overall cycling performance of the T44 graphite/Li cells containing electrolyte with $6: 4$ ratio is comparable to the one with AN:FEC 1:1 electrolyte formulation (Figure 2d). Nevertheless, the capacity retention based on the $5^{\text {th }}$ cycle amounts to 99.7 in cycle 100 for the 1:1 mixture.

Besides the cycling behavior of graphite/Li cells when using different AN:FEC solvent mixtures, conductivity values of the investigated AN-based electrolytes must be taken into account, especially when considering the reported excellent low temperature behavior of nitriles and their extraordinary high conductivity [13].

AN-based electrolytes, independent of the amount of FEC, deliver higher conductivity values compared to the $1 \mathrm{M} \mathrm{LiPF} 6$ in EC:DEC (3:7) standard electrolyte (Figure 3). Especially at low temperatures around $0{ }^{\circ} \mathrm{C}$, the conductivity of the $\mathrm{AN}: \mathrm{FEC}$ mixtures are at least three times higher compared to the organic carbonate-based electrolyte $(3.49 \mathrm{mS} / \mathrm{cm})$. The conductivity values of the electrolytes $1 \mathrm{M} \mathrm{LiPF}_{6}$ in AN:FEC (7:3) and $1 \mathrm{M}$ $\mathrm{LiPF}_{6}$ in AN:FEC (6:4) are at every temperature similar (small variations are in between the error margin of the system). At these concentrations, the addition of FEC has no major impact on the ionic conductivity of the AN-based electrolyte. At a temperature of $-20^{\circ} \mathrm{C}$, the $7: 3$ as well as the $6: 4$ ratio AN:FEC mixture-based electrolytes deliver a conductivity value of $6.42 \mathrm{mS} / \mathrm{cm}$ and at $0{ }^{\circ} \mathrm{C}$ a conductivity value of $11.44 \mathrm{mS} / \mathrm{cm}$. At $20^{\circ} \mathrm{C}$, a value of $17.65 \mathrm{mS} / \mathrm{cm}$ was measured. From the conductivity measurements it is proven that all the investigated AN:FEC mixtures deliver high conductivity compared to the commercially used organic solvent-based electrolyte [7]. The same is valid for temperatures below the room temperature. To investigate this property further, low-temperature cycling investigations were performed at $0{ }^{\circ} \mathrm{C}$ in graphite/Li cells. The CCCP 


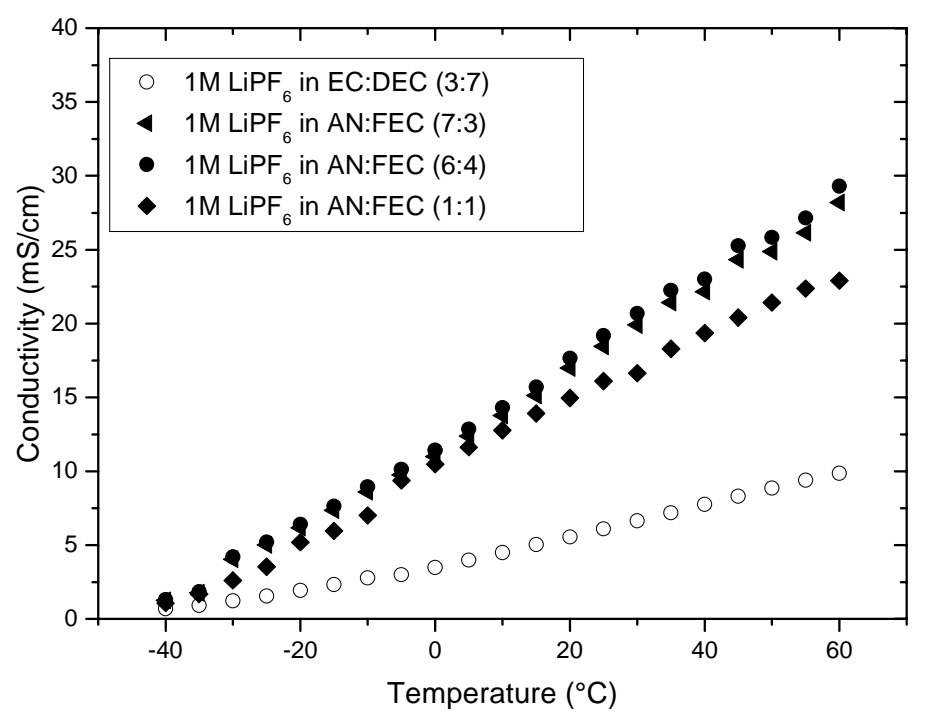

Figure 3. Temperature-dependent conductivity measurements of $1 \mathrm{M} \mathrm{LiPF}_{6}$ in AN:FEC (7:3), $1 \mathrm{M} \mathrm{LiPF}_{6}$ in AN:FEC (6:4), $1 \mathrm{M} \mathrm{LiPF}_{6}$ in AN:FEC (1:1) as well as $1 \mathrm{M} \mathrm{LiPF}_{6}$ in EC:DEC (3:7) in the temperature range between $-40{ }^{\circ} \mathrm{C}$ and $60{ }^{\circ} \mathrm{C}$.

measurements of the AN-based electrolytes and of $1 \mathrm{M} \mathrm{LiPF}_{6}$ in EC:DEC $(3: 7)$ at $0{ }^{\circ} \mathrm{C}$ are depicted in Figure 4.

For the graphite/Li cell cycled with $1 \mathrm{M} \mathrm{LiPF} 6$ in AN:FEC (7:3), a specific capacity of $\approx 317 \mathrm{mAh} / \mathrm{g}$ and a Coulombic efficiency of $99.0 \%$ were reached in the $5^{\text {th }}$ charge/discharge cycle (Figure $4 \mathrm{a}$ ). After the formation cycles, the specific capacity value decreases to $302 \mathrm{mAh} / \mathrm{g}$ in the $100^{\text {th }}$ cycle. The overall capacity retention amounts to $95.3 \%$ based on the $5^{\text {th }}$ cycle. The Coulombic efficiency values indicate good cycling performance over 100 charge/ discharge cycles. In Figure $2 b$, the CCCP cycling of graphite/Li cell using $1 \mathrm{M} \mathrm{LiPF}_{6}$ in AN:FEC (6:4) shows a cycling performance without capacity fading compared to the aforementioned performance of the $1 \mathrm{M} \mathrm{LiPF}_{6}$ in $\mathrm{AN}: \mathrm{FEC}(7: 3)$ electrolyte formulation. Based on the $5^{\text {th }}$ cycle the specific capacity values of the cell cycled with $1 \mathrm{M}$ $\mathrm{LiPF}_{6}$ in AN:FEC (6:4) are similar compared to the cell cycled with $1 \mathrm{M} \mathrm{LiPF}_{6}$ in $\mathrm{AN}: \mathrm{FEC}(7: 3)$ as specific capacity of $\approx 320 \mathrm{mAh} / \mathrm{g}$ and a Coulombic efficiency of $97.7 \%$ are obtained. After the formation cycles, the specific capacity value decreases to $277 \mathrm{mAh} / \mathrm{g}$ in the $100^{\text {th }}$ cycle. The capacity retention based on the $5^{\text {th }}$ cycle amounts to $86.6 \%$. The cycling performance of the electrolyte based on $1 \mathrm{M} \mathrm{LiPF}_{6}$ in $\mathrm{AN}: \mathrm{FEC}(1: 1)$ is depicted in Figure $4 \mathrm{c}$. In the $5^{\text {th }}$ cycle, a specific capacity of $\approx 290 \mathrm{mAh} / \mathrm{g}$ and a Coulombic efficiency of $97.5 \%$ were reached. The capacity retention based on the $5^{\text {th }}$ cycle amounts to $100 \%$. Nevertheless, the specific capacity drops to $259 \mathrm{mAh} / \mathrm{g}$ in the $11^{\text {th }}$ cycle before recovering to $290 \mathrm{mAh} / \mathrm{g}$ in the $100^{\text {th }}$ cycle. Compared to AN-based electrolytes, the standard $1 \mathrm{M} \mathrm{LiPF} 6$ in EC:DEC 3:7 (wt.\%) electrolyte shows decreased specific capacity as well as unstable Coulombic efficiency values during cycling (Figure 4d). In the fifth cycle, a specific capacity of $\approx 290 \mathrm{mAh} / \mathrm{g}$ and a Coulombic efficiency of $96.3 \%$ are obtained. In the $100^{\text {th }}$ cycle, the specific capacity drops down to $204 \mathrm{mAh} / \mathrm{g}$. The capacity retention based on the $5^{\text {th }}$ cycle amounts to $70.3 \%$.

Furthermore, the compatibility of AN:FEC-based electrolytes with different cathode materials, namely LMO and LFP was investigated. The oxidative stability of the electrolyte was determined by means of LSV with lithium manganese oxide (LMO) as the WE (Figure 5).

Starting with the $1 \mathrm{M} \mathrm{LiPF} 6$ in EC/DEC (3:7) electrolyte formulation, the maximum of the deinsertion peaks of LMO are positioned at $\approx 4.05 \mathrm{~V}$ vs. $\mathrm{Li} / \mathrm{Li}^{+}$and $4.16 \mathrm{~V}$ vs. $\mathrm{Li} / \mathrm{Li}^{+}$[46]. The $1 \mathrm{M} \mathrm{LiPF}{ }_{6}$ in EC:DEC (3:7) electrolyte is electrochemically stable up to $4.8 \mathrm{~V}$ vs. $\mathrm{Li} / \mathrm{Li}^{+}$ [47]. As AN-based electrolytes decompose at 

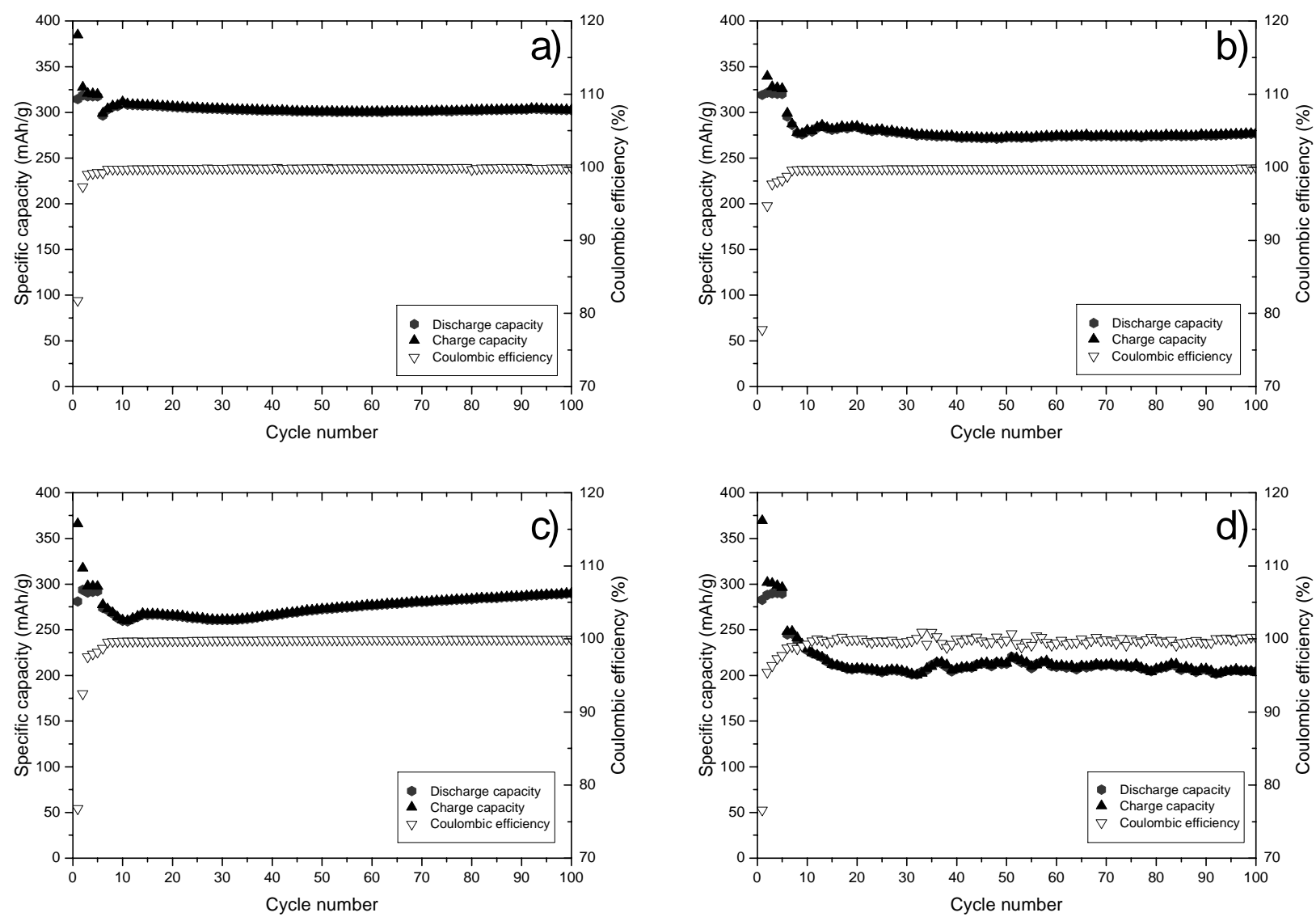

Figure 4. $\mathrm{CCCP}$ cycling of graphite/Li cells at $0{ }^{\circ} \mathrm{C}$ in the potential range between 1.50 and $0.02 \mathrm{~V} \mathrm{vs.} \mathrm{Li} / \mathrm{Li}^{+}$ containing a) $1 \mathrm{M} \mathrm{LiPF}_{6}$ in $7: 3 \mathrm{AN}: \mathrm{FEC}$, b) $1 \mathrm{M} \mathrm{LiPF}_{6}$ in $6: 4 \mathrm{AN}: \mathrm{FEC}$, c) $1 \mathrm{M} \mathrm{LiPF}_{6}$ in 1:1 AN:FEC and d) $1 \mathrm{M} \mathrm{LiPF}_{6}$ in EC:DEC 3:7 as electrolyte.

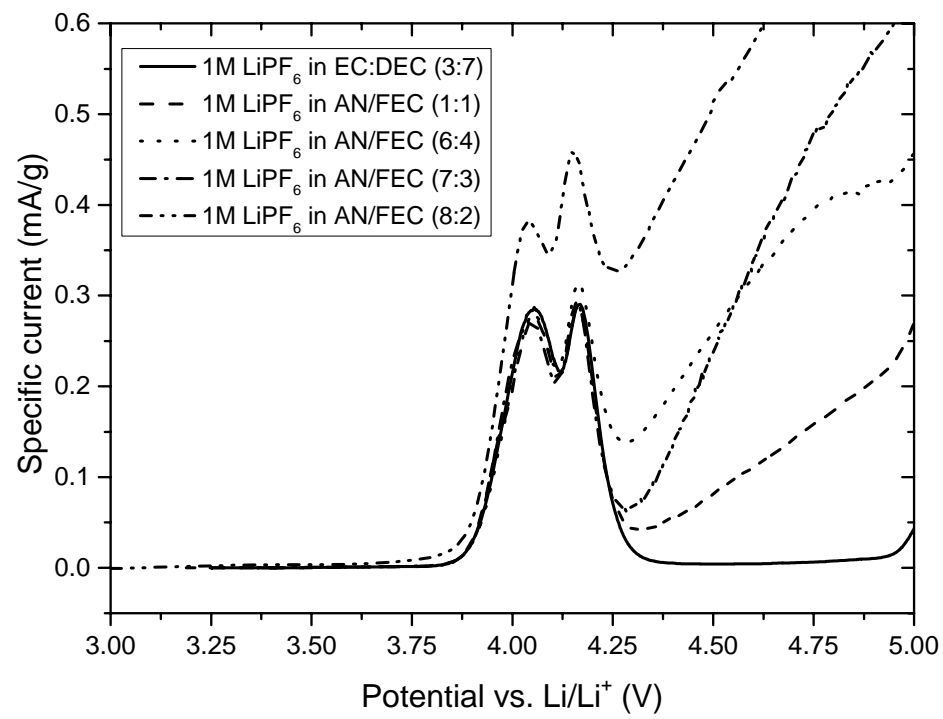

Figure 5. Electrochemical stability window of investigated electrolytes containing $1 \mathrm{M} \mathrm{LiPF}_{6}$ in different AN:FEC ratios and $1 \mathrm{M} \mathrm{LiPF}_{6}$ in EC:DEC (3:7) (wt.\%) on LMO (WE), at scan rate of $100 \mu \mathrm{V} / \mathrm{s}$. 
$\approx 4.25 \mathrm{~V}$ vs. $\mathrm{Li} / \mathrm{Li}^{+}$, they are not suitable for high voltage application [47]. Due to the decomposition potential of AN $\left(4.25 \mathrm{~V}\right.$ vs. $\mathrm{Li}^{2} / \mathrm{Li}^{+}$.), depicted in Figure 5, the only common cathode material which may show stable and reproducible longterm cycling behavior with the AN-based electrolytes is LFP, due to its lower cut off potential. For this reason, the selected AN-based electrolyte formulations were further investigated in LFP/Li cells (Figure 6a, b) and graphite/LFP cells (Figure 6c). For comparison, $1 \mathrm{M} \mathrm{LiPF}_{6}$ in EC:DEC (3:7) was investigated in graphite/LFP cells, as well.

Starting with the AN:FEC (1:1) mixture, as depicted in Figure 6a, LFP-based cells show stable cycling performance without fading over 100 charge/discharge cycles and Coulombic efficiency values amount to $99.9 \%$. For the specific capacity in the first cycle, a value of $148 \mathrm{mAh} / \mathrm{g}$ was reached (Coulombic efficiency value amounts to $96.7 \%)$. However, the specific capacity drops to $145 \mathrm{mAh} / \mathrm{g}$ for the next 97 charge/discharge cycles, leading to a capacity retention of $99.3 \%$ in the $100^{\text {th }}$ cycle (based on the $5^{\text {th }}$ cycle). Figure $6 \mathrm{~b}$ shows the cycling performance of the cell containing the most promising electrolyte formulation, $1 \mathrm{M}$ $\mathrm{LiPF}_{6}$ in AN:FEC (7:3). A specific capacity of $146 \mathrm{mAh} / \mathrm{g}$ was reached in the first cycle (Coulombic efficiency value amounts to $96.4 \%$ ). Within the next 97 cycles the specific capacity drops down to $142 \mathrm{mAh} / \mathrm{g}$ leading to a capacity retention based on the $5^{\text {th }}$ cycle of $99.2 \%$ in the $100^{\text {th }}$ cycle.

Since it was shown that the above discussed ANbased electrolyte with the ratio 7:3 shows a good
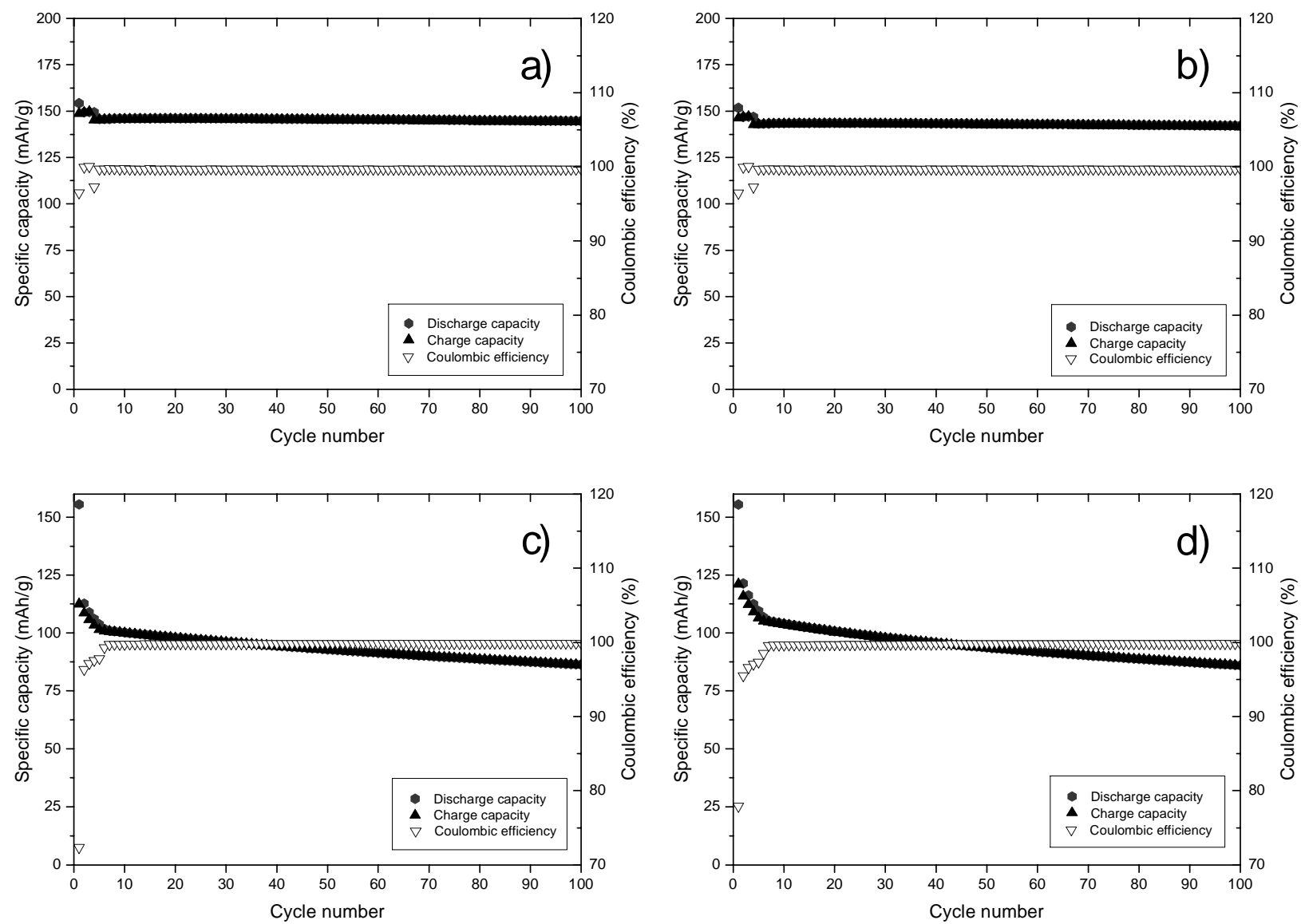

Figure 6. Cycling profiles of $\mathrm{LFP} / \mathrm{Li}$ cells in the potential range between $3.0-3.9 \mathrm{~V}$ vs. $\mathrm{Li} / \mathrm{Li}^{+}$using a) $1 \mathrm{M} \mathrm{LiPF}$ in AN:FEC (1:1), and b) $1 \mathrm{M} \mathrm{LiPF}_{6}$ in AN:FEC (7:3) as well as CCCV measurements of graphite/LFP cell in the voltage range between 2.5 - $3.9 \mathrm{~V}$ using c) $1 \mathrm{M} \mathrm{LiPF}_{6}$ in $\mathrm{AN}: \mathrm{FEC}(7: 3)$, and d) $1 \mathrm{M} \mathrm{LiPF}_{6}$ in EC:DEC (3:7). 
cycling performance on both anode and cathode material, the performance of the electrolytes in graphite/LFP cells was investigated next (ANbased electrolyte Figure $6 \mathrm{c}, 1 \mathrm{M} \mathrm{LiPF}_{6}$ in EC:DEC (3:7) Figure 6d). In the case of $1 \mathrm{M} \mathrm{LiPF} 6$ in AN:FEC (7:3), a slight fading over 100 charge/ discharge cycles is observed, leading to a capacity retention of $82.8 \%$ (based on the $5^{\text {th }}$ cycle, Figure 6c) The specific capacity decreases from the initial cycles $(112 \mathrm{mAh} / \mathrm{g})$ to $87 \mathrm{mAh} / \mathrm{g}$ in the $100^{\text {th }}$. Nevertheless, the Coulombic efficiency values are constant over all 100 charge/discharge cycles. This behavior is evident when using $1 \mathrm{M}$ $\mathrm{LiPF}_{6}$ in EC:DEC (3:7) as the electrolyte, where the specific capacity in the initial cycle amounts to value of $121 \mathrm{mAh} / \mathrm{g}$ (capacity retention of $78.9 \%$ in the $5^{\text {th }}$ cycle) and decreases to $86 \mathrm{mAh} / \mathrm{g}$ in the last cycle. After showing the beneficial behavior of FEC as the co-solvent for AN-based electrolyte in terms of electrochemical performance, the electrochemical decomposition of $\mathrm{AN}$ on the graphite surface was investigated by means of XPS measurements. Figure 7 depicts XPS F 1s and $\mathrm{N} 1 \mathrm{~s}$ core spectra of graphite electrodes cycled with different amounts of FEC in the ANbased electrolyte by comparing different AN:FEC ratios (Figure 7).

Figure 7 depicts the XPS F 1s and N 1s core spectra of graphite electrodes cycled in the presence of $1 \mathrm{M} \mathrm{LiPF}_{6}$ in $\mathrm{AN}, 1 \mathrm{M} \mathrm{LiPF}$ in AN:FEC (1:1) as well as $1 \mathrm{M} \mathrm{LiPF} 6$ in $\mathrm{AN}: F E C(7: 3)$ as the

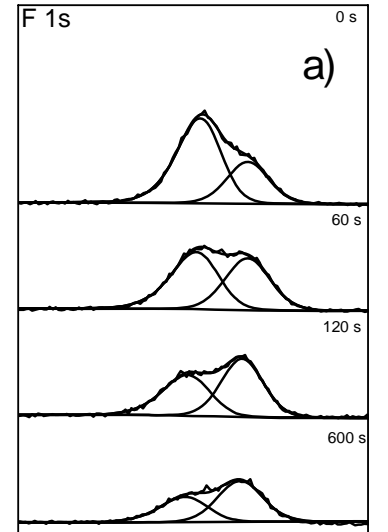

$\begin{array}{lllllllllllll}692690 & 688 & 686 & 684 & 682 & 680 & 692 & 690 & 688 & 686 & 684 & 682 & 680\end{array}$ Binding Energy / eV

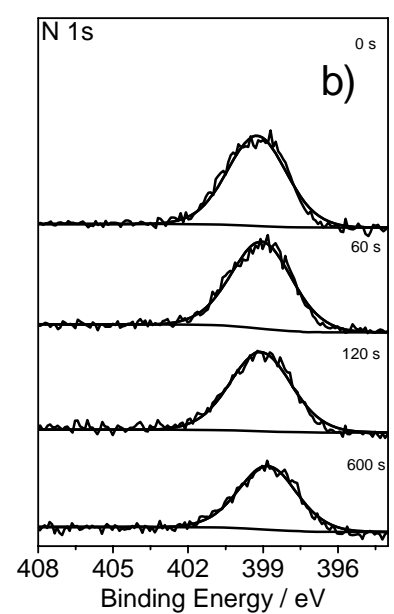

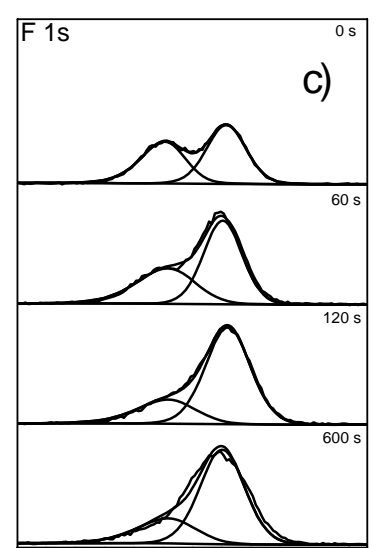

Binding Energy / eV

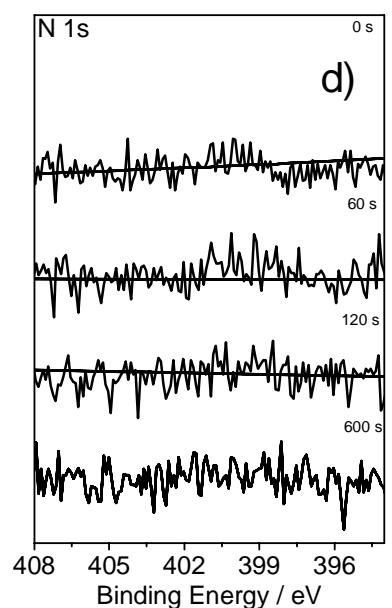

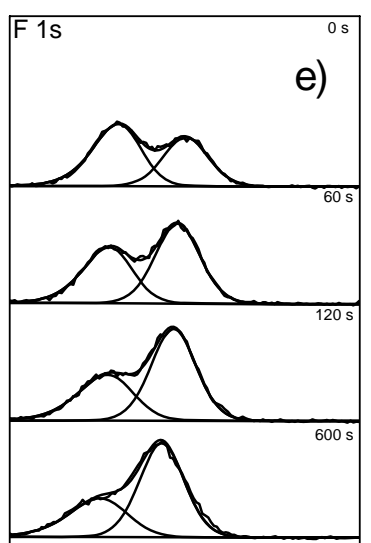

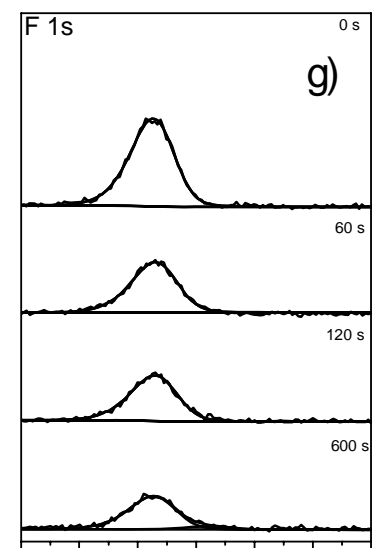

Binding Energy / eV
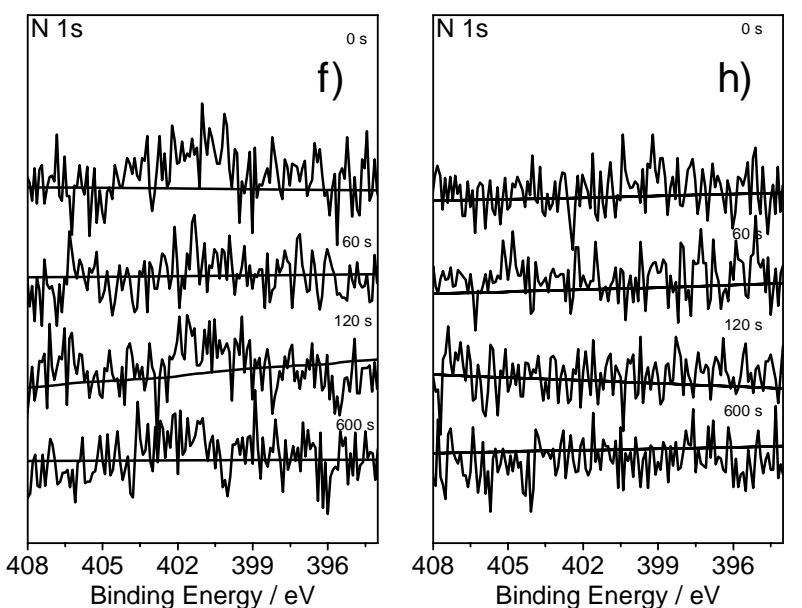

Figure 7. XPS F 1s and N 1s core spectra of graphite electrodes, after 5 charge/discharge cycles at $0.1 \mathrm{C}$ in a graphite/LFP cell using different amounts of FEC in the electrolyte: a,b) pure AN without FEC, c,d) AN:FEC (1:1), e,f) AN:FEC (7:3) and g,h) pristine electrode. The electrodes where sputtered for $60 \mathrm{~s}, 120 \mathrm{~s}$ and $600 \mathrm{~s}$. 
electrolyte. As reference spectra, the XPS F 1s and $\mathrm{N} 1 \mathrm{~s}$ core spectra of a pristine graphite electrode are shown. In the F 1s spectra of the pristine electrode (Figure $7 \mathrm{~g}$ ) one signal located at $687 \mathrm{eV}$ is observable, which can be attributed to the used binder PVdF. The decreasing of the peak during sputtering is related to the decomposition of the binder during sputtering [48]. No nitrogen signal could be found on the pristine electrode surface (Figure $7 \mathrm{~h}$ ). In the $\mathrm{F} 1 \mathrm{~s}$ spectra of the cycled electrodes (Figure 7 a,c,e) an additional signal occurs at $685 \mathrm{eV}$, attributed to lithium fluoride (LiF). $\mathrm{LiF}$ is formed due to the decomposition of the conducting salt $\mathrm{LiPF}_{6}$ in ultra-high vacuum during sputtering. It is shown that the amount of $\mathrm{LiF}$ increases relatively to the PVdF peak with increasing sputter time (Figure 7a). This could be explained by the role of $\mathrm{LiF}$ in the $\mathrm{SEI}$, as $\mathrm{LiF}$ is the main component of the inorganic part of the SEI, which is close to the electrode surface [48]. Furthermore, LiF is generated when FEC is present in the electrolyte formulation due to its decomposition during galvanostatic cycling. Therefore, the signal intensity of LiF is higher compared to the PVdF peak in the case, where FEC is used as the co-solvent (Figure $7 \mathrm{c}, \mathrm{e}$ ). The decomposition of $\mathrm{AN}$ was further evidenced from the XPS N 1s core spectra. The N 1s spectra of the electrode, cycled without the addition of FEC, show a signal at $399 \mathrm{eV}$ resulting from the decomposition reaction of $\mathrm{AN}$ on the graphite electrode (Figure 7b). For the pristine electrode (Figure $7 \mathrm{~h}$ ) and the electrodes where FEC is used as the electrolyte component (Figure 7 d,f), no signal in the XPS N 1s spectra is observed. This demonstrates, that $\mathrm{AN}$ is not decomposed on the graphite electrode, due to the formation of an effective SEI in the presence of FEC. Table 1 summarizes the surface concentration of the above-mentioned XPS measurements.

The results obtained from the XPS measurements fit very well to the electrochemical measurements performed. As already mentioned, AN alone is not able to prevent graphite against exfoliation. It was shown that a AN:FEC (1:1) ratio shows a stable long-term cycling performance on both graphite half and full cells. This correlates well with the above XPS measurements, showing that AN is not

Table 1. Surface concentration (a.u.) of LiF and $\mathrm{N} 1 \mathrm{~s}$ with mean deviation in brackets. Calculations are based on two measurement points for each electrode.

\begin{tabular}{|c|c|c|c|c|}
\hline \multicolumn{5}{|c|}{ AN-based electrolyte:surface concentration (a.u.) } \\
\hline Sputter time/s & 0 & 60 & 120 & 600 \\
\hline LIF/at. \% & $6.62(0.67)$ & $8.63(0.67)$ & $8.49(0.54)$ & $7.04(1.45)$ \\
\hline N 1s/at. \% & $25.70(2.72)$ & $25.05(3.22)$ & $23.97(0.91)$ & $22.22(0.29)$ \\
\hline \multicolumn{6}{|c|}{ AN:FEC (1:1) based electrolyte:surface concentration (a.u.) } \\
\hline Sputter time/s & 0 & 60 & 120 & 600 \\
\hline LIF/at. \% & $13.22(0.46)$ & $17.17(0.38)$ & $19.81(2.37)$ & $19.15(2.43)$ \\
\hline N 1s/at. \% & $0(0)$ & $0(0)$ & $0(0)$ & $0(0)$ \\
\hline \multicolumn{7}{|c|}{ AN:FEC (7:3) based electrolyte:surface concentration (a.u.) } \\
\hline Sputter time/s & 0 & 60 & 120 & 600 \\
\hline LIF/at. \% & $8.02(0.12)$ & $15.18(1.39)$ & $17.35(1.76)$ & $16.30(1.15)$ \\
\hline N 1s/at. \% & $0(0)$ & $0(0)$ & $0(0)$ & $0(0)$ \\
\hline \multicolumn{7}{|c|}{ Reference electrode (pristine):surface concentration (a.u.) } \\
\hline Sputter time/s & 0 & 60 & 120 & 600 \\
\hline LIF/at. \% & $0.86(0.84)$ & $1.33(0.73)$ & $1.52(1.47)$ & $1.32(0.93)$ \\
\hline
\end{tabular}


decomposing on the graphite surface. Nevertheless, the amount of FEC may be reduced, due to its costs. The XPS results for the AN:FEC (7:3) ratio, which already shows great cycling performance, proved that this ratio inhibits AN decomposition on the graphite electrode.

\section{CONCLUSION}

AN-based electrolytes containing FEC as the cosolvent were investigated in an effort to overcome the incompatibility of pure AN-based electrolytes with graphite anodes. Starting with a AN:FEC (1:1) ratio, an effective SEI could be formed. The decomposition of FEC was electrochemically measured by the cyclic voltammetry technique, where a peak at $1.5 \mathrm{~V}$ vs. $\mathrm{Li} / \mathrm{Li}^{+}$clearly points out the decomposition of FEC. This fact was further proven by XPS sputter depth profiling. A stable galvanostatic cycling could be achieved over 100 charge/discharge cycles. Having in mind that FEC increases the cost of the electrolyte and may also decrease the extraordinary high ionic conductivity of $\mathrm{AN}$, different $\mathrm{AN}$ :FEC ratios were investigated with various electrochemical techniques. Longterm cycling measurements showed that AN:FEC (7:3) and AN:FEC (6:4) do not show a significant difference compared to the AN:FEC (1:1) ratio when using graphite/Li cells. Further decreasing the amount of FEC leads to a strong capacity loss and fading after the initial cycles, indicating that the amount of FEC in the (8:2) mixture is not sufficient to protect AN against further decomposition. The conductivity measurements showed that higher amount of FEC in the electrolyte (1:1 ratio) has a negative influence on the temperature dependence of the conductivity. On the other hand, the results of the electrolytes containing $30 \%$ and $40 \%$ FEC are very similar and higher conductivity values especially at higher temperatures are reached. Graphite/Li cell measurements at $0^{\circ} \mathrm{C}$ showed stable cycling performance for the 7:3 ratio. To allow for the application of AN:FEC in lithium-ion cells, electrochemical stability window measurements were performed, which indicated that all the investigated AN-based electrolytes suffer from a low decomposition potential $\left(4.25 \mathrm{~V}\right.$ vs. $\left.\mathrm{Li} / \mathrm{Li}^{+}\right)$. However, this potential window fits well with the operation window of the LFP electrode. The results obtained for LFP/Li and graphite/LFP cells indicated a stable long-term cycling performance when using $1 \mathrm{M} \mathrm{LiPF} 6$ in AN:FEC (7:3) as the electrolyte, with a very high ionic conductivity and low temperature performance compared to the state-ofthe art organic carbonate-based electrolyte.

\section{ACKNOWLEDGMENT}

Financial support by the German Federal Ministry for Education and Research (BMBF) within the project Electrolyte Lab 4E (project reference $03 \mathrm{X} 4632$ ) is gratefully acknowledged.

\section{CONFLICT OF INTEREST STATEMENT}

The authors certify that they have no affiliations with or involvement in any organization or entity with any financial interest (such as honoraria; educational grants; participation in speakers' bureaus; membership, employment, consultancies, stock ownership, or other equity interest; and expert testimony or patent-licensing arrangements), or non-financial interest (such as personal or professional relationships, affiliations, knowledge or beliefs) in the subject matter or materials discussed in this manuscript.

\section{REFERENCES}

1. Lu, L., Han, X., Li, J., Hua, J. and Ouyang, M. 2013, J. Power Sources, 226, 272-288.

2. Winter, M. and Brodd, R. J. 2004, Chem. Rev., 104(10), 4245-4269.

3. Wagner, R., Preschitschek, N., Passerini, S., Leker, J. and Winter, M. 2013, J. Appl. Electrochem., 43(5), 481-496.

4. Placke, T., Kloepsch, R., Dühnen, S. and Winter, M. 2017, J. Solid State Electrochem., 21(7), 1939-1964.

5. Andre, D., Kim, S.-J., Lamp, P., Lux, S. F., Maglia, F., Paschos, O. and Stiaszny, B. 2015, J. Mater. Chem. A, 3(13), 6709-6732.

6. Schmuch, R., Wagner, R., Hörpel, G., Placke, T. and Winter, M. 2018, Nat. Energy, 3(4), 267.

7. Cekic-Laskovic, I., von Aspern, N., Imholt, L., Kaymaksiz, S., Oldiges, K., Rad, B. R. and Winter, M. 2017, Top. Curr. Chem., $375(2), 37$.

8. Xu, K. 2004, Chem. Rev., 104(10), 43034417. 
9. Schmitz, R. W., Murmann, P., Schmitz, R., Müller, R., Krämer, L., Kasnatscheew, J., Isken, P., Niehoff, P., Nowak, S., Röschenthaler, G.-V., Ignatiev, N., Sartori, P., Passerini, S., Kunze, M., Lex-Balducci, A., Schreiner, C., Cekic-Laskovic, I. and Winter, M. 2014, Prog. Solid State Chem., 42(4), 65-84.

10. Isken, P., Dippel, C., Schmitz, R., Schmitz, R. W., Kunze, M., Passerini, S., Winter, M. and Lex-Balducci, A. 2011, Electrochim. Acta, 56(22), 7530-7535.

11. Yamada, Y., Furukawa, K., Sodeyama, K., Kikuchi, K., Yaegashi, M.; Tateyama, Y. and Yamada, A. 2014, J. Am. Chem. Soc., 136(13), 5039-5046.

12. Han, S.-D., Borodin, O., Allen, J. L., Seo, D. M., McOwen, D. W., Yun, S.-H. and Henderson, W. A. 2013, J. Am. Chem. Soc., 160(11), A2100-A2110.

13. Xu, K. 2014, Chem. Rev., 114(23), 1150311618.

14. Wakihara, M. 2001, Mater. Sci. Eng. R, 33(4), 109-134.

15. Peled, E. 1979, J. Am. Chem. Soc., 126(12), 2047-2051.

16. Peled, E., Golodnitsky, D., Menachem, C. and Bar-Tow, D. 1998, J. Am. Chem. Soc., 145(10), 3482-3486.

17. Zhang, S. S., Ding, M. S., Xu, K., Allen, J. and Jow, T. R. 2001, Electrochem. SolidState Lett., 4(12), A206-A208.

18. Winter, M. 2009, Z. Phys. Chem., 223(1011), 1395-1406.

19. Winter, M., Besenhard, J. O., Spahr, M. E. and Novak, P. 1998, Adv. Mater., 10(10), 725-763.

20. Wagner, M. R., Albering, J. H., Möller, K. C., Besenhard, J. O. and Winter, M. 2005, Electrochem. Commun., 7(9), 947-952.

21. Wagner, R., Brox, S., Kasnatscheew, J., Gallus, D. R., Amereller, M., CekicLaskovic, I. and Winter, M. 2014, Electrochem. Commun., 40, 80-83.

22. Röser, S., Lerchen, A., Ibing, L., Cao, X., Kasnatscheew, J., Glorius, F., Winter, M. and Wagner, R. 2017, Chem. Mater., 29(18), 7733-7739.

23. Kasnatscheew, J., Schmitz, R. W., Wagner, R., Winter, M. and Schmitz, R. 2013, J. Electrochem. Soc., 160(9), A1369-A1374.
24. An, Y., Zuo, P., Cheng, X., Liao, L. and Yin, G. 2011, Electrochim. Acta, 56(13), 4841-4848.

25. Korepp, C., Santner, H., Fujii, T., Ue, M., Besenhard, J., Möller, K.-C. and Winter, M. 2006, J. Power Sources, 158(1), 578-582.

26. Winter, M. 2009, Z. Phys. Chem., 223(1011), 1395-1406.

27. Aurbach, D., Gamolsky, K., Markovsky, B., Gofer, Y., Schmidt, M. and Heider, U. 2002, Electrochim. Acta, 47(9), 1423-1439.

28. Wang, Y., Nakamura, S., Tasaki, K. and Balbuena, P. B. 2002, J. Amer. Chem. Soc., 124(16), 4408-4421.

29. Wrodnigg, G. H., Besenhard, J. O. and Winter, M. 1999, J. Electrochem. Soc., 146(2), 470-472.

30. Yao, W., Zhang, Z., Gao, J., Li, J., Xu, J., Wang, Z. and Yang, Y. 2009, Energy Environ. Sci., 2(10), 1102-1108.

31. Panitz, J.-C., Wietelmann, U., Wachtler, M., Ströbele, S. and Wohlfahrt-Mehrens, M. 2006, J. Power Sources, 153(2), 396-401.

32. Wagner, R., Streipert, B., Kraft, V., Reyes Jiménez, A., Röser, S., Kasnatscheew, J., Gallus, D. R., Börner, M., Mayer, C. and Arlinghaus, H. F. 2016, Adv. Mater. Interfaces, 3(15).

33. Gallus, D. R., Wagner, R., Wiemers-Meyer, S., Winter, M. and Cekic-Laskovic, I. 2015, Electrochim. Acta, 184, 410-416.

34. Kasnatscheew, J., Evertz, M., Streipert, B., Wagner, R., Klöpsch, R., Vortmann, B., Hahn, H., Nowak, S., Amereller, M. and Gentschev, A.-C. 2016, Phys. Chem. Chem. Phys., 18(5), 3956-3965.

35. Edström, K., Gustafsson, T. and Thomas, J. O. 2004, Electrochim. Acta, 50(2-3), $397-$ 403.

36. Niehoff, P. and Winter, M. 2013, Langmuir, 29(51), 15813-15821.

37. Wagner, R., Korth, M., Streipert, B., Kasnatscheew, J., Gallus, D. R., Brox, S., Amereller, M., Cekic-Laskovic, I. and Winter, M. 2016, ACS Appel. Mater. Interfaces, 8(45), 30871-30878.

38. Profatilova, I. A., Stock, C., Schmitz, A., Passerini, S. and Winter, M. 2013, J. Power Sources, 222, 140-149. 
39. Doi, T., Takeda, K., Fukutsuka, T., Iriyama, Y., Abe, T. and Ogumi, Z. 2005, Carbon, 43(11), 2352-2357.

40. Etacheri, V., Haik, O., Goffer, Y., Roberts, G. A., Stefan, I. C., Fasching, R. and Aurbach, D. 2012, Langmuir, 28(1), 965-976.

41. McMillan, R., Slegr, H., Shu, Z. X. and Wang, W. 1999, J. Power Sources, 81-82, 20-26.

42. Heine, J., Hilbig, P., Qi, X., Niehoff, P., Winter, M. and Bieker, P. 2015, J. Electrochem. Soc., 162(6), A1094-A1101.

43. Kasnatscheew, J., Placke, T., Streipert, B., Rothermel, S., Wagner, R.; Meister, P., Laskovic, I. C. and Winter, M. 2017, J. Electrochem. Soc., 164(12), A2479-A2486.
44. Wagner, M. R., Raimann, P. R., Trifonova, A., Möller, K. C., Besenhard, J. O. and Winter, M. 2004, Anal. Bioanal. Chem., 379(2), 272-276.

45. Winter, M., Wrodnigg, G. H., Besenhard, J. O., Biberacher, W. and Novak, P. 2000, J. Electrochem. Soc., 147(7), 2427-2431.

46. Xu, K., Ding, S. P. and Jow, T. R. 1999, J. Electrochem. Soc., 146(11), 4172-4178.

47. Kasnatscheew, J., Streipert, B., Röser, S., Wagner, R., Laskovic, I. C. and Winter, M. 2017, Phys. Chem. Chem. Phys., 19(24), 16078-16086.

48. Niehoff, P., Passerini, S. and Winter, M. 2013, Langmuir, 29(19), 5806-5816. 